\title{
Flashcard computer generated imagery medicinal plant for orthopedagogic education
}

\author{
Rohman Dijaya ${ }^{1}$, Noor Mayaminiy Maulidah ${ }^{2}$, and Dahlan Abdullah ${ }^{3}$ \\ ${ }^{1}$ Universitas Muhammadiyah Sidoarjo, Department of Informatics, Sidoarjo, Indonesia \\ ${ }^{2}$ Universitas Malikussaleh, Department of Informatics, Aceh, Indonesia
}

\begin{abstract}
The Indonesia natural wealth of tropical forest store various plants such as ornamental plants, fruits, vegetables, spices and medicinal plants. Medicinal plants are a variety of plants that are recognized as plants for medicines. However, due to the lack of community knowledge about medicinal plants. So it takes the application of learning about the benefits of medicinal plants to the community, especially to children. Orthopedagogic Orthodontic Objects are exceptional children, who have abnormalities that require special educator services. Learning media associated with motor censorship can overcome the limitations of deaf and tuneless children who can improve the motor skills of the child. Because children with hearing impairment and speech have a lack of understanding of spoken and written language. Development of Computer Science technology today, thus encouraging the educational process to be more interesting and applicable in order to improve the quality of education media and learning interests of learners. Augmented Reality (AR) learning media is a technique of displaying objects directly by directing the camera to a real (marker) object. The aim of current developd application are to show 3 Dimensional interactive learning media using a marker of flashcards about medicinal plants as many as 20 types of medicinal plants. This is intended to facilitate the user especially on orthopedagogic education in recognizing the types of plants that are efficacious for treatment.
\end{abstract}

\section{Background}

Indonesia is an archipelagic country located in the equatorial region and is known as one of the tropical countries that has a vast and diverse conservation area. The natural wealth of tropical forests of Indonesia, store various plants such as ornamental plants, fruits, vegetables, spices, and medicinal plants. Medicinal plants are a variety of plants that are recognized as plants that have pharmacological effects [1]. Based on several studies, in Indonesia there are about 1300 species of medicinal plants and about 300 species have been used for traditional treatment, while according World Health Organization (WHO) more than 20.000 species of medicine plant used by people around the world. Medicinal plants can be easily found compared to us because Indonesia knows about herbal medicine since thousands of years ago [2]. Tradition of treatment of a society can not be separated from the local cultural linkage. Perceptions about the concept of sickness, health, and the diversity of plant species used as traditional medicine are formed through a process of socialization that is hereditary to be believed and believed to be true [3]. Traditional medicine from medicinal plants was originally known as herbal medicine, until now herbal medicine is still believed as a panacea to treat various diseases even been developed in modern industry [4]. As the times progress, more and more people tend to choose instant and easy consumerist patterns. One of them in terms of treatment, not a few people who prefer to consume modern treatment made of chemicals than choosing traditional medicine. This can happen because of the lack of community knowledge about medicinal plants. So, most Indonesian people do not know what kind of plants that can be used for traditional medicine. Because almost $50 \%$ of the plant species have not been used for treatment [5]. Consequently, it is necessary application of learning about the benefits of medicinal plants to the community, especially to children from an early age and children with special needs or orthopedagogic area.

Ortopedagogic Orthodontic Objects are extraordinary children, who have a disorder or problem in such a way that requires special educator services. Orthopedagogic method guarantees the arrival of the right to education to children extraordinary. Children who are deaf and hard of speech have a lack of understanding oral and written language can cause children with hearing impairment and speech impaired interpret everything wrong or negative that can cause pressure on his emotions. Unstable emotion due to lack of language vocabulary and the other side due to the influence received from outside [6]. Along with the current rapid technological developments, thus encouraging the educational process to be more interesting and applicable in order to improve the quality of education and learning interests of

\footnotetext{
* Corresponding author: $\underline{\text { rohman.dijaya } @ \text { umsida.ac.id }}$
} 
learners. Learning media Augmented Reality (AR) is a technique of displaying objects directly by directing the camera to the object (marker) in the real world. Because the learning method used in the 2013 curriculum for primary school level is to use thematic learning approach. Where in this method teachers are expected to be able to develop more creative ideas or develop their own learning ideas. To achieve the goal of thematic learning then made various kinds of learning one way is to create an interactive learning media which provides between pleasure and learning. Many scientists also utilizes Augmented Reality is "Augmented Reality Making About Animal Introduction For Early Childhood Based Android Using Image Tracking Method Vuforia" is developing Augmented Reality based application on Android using AR Vuforia library applied to help introducing animals to early childhood. The application will become a new attraction in the field of learning media, designed with a more colorful and interactive concept that will provide a new learning atmosphere for children [7]. Augmented Reality for education because connections between augmented reality (AR) and traditional learning based on textbooks through the wellknown augmented books also known as "magic books. 3 Dimension Based Educational Learning Apparatus For Playing And Kindergarten Groups" that is realizing 3 dimensional educational tools that can help teachers in providing learning in the form of observation of wake, objects, tools in Muslimat kindergarten Pongangan Gresik East Java Indonesia during the teaching-learning process in the classroom and attract students to recognize the shape and object of space. Because teachers have difficulty in the learning process because when they have to bring props that match the theme will be taught, whereas not all props in real form can be easily taken to school [8].

This research proposed application of learning about medicinal plants can be developed starting from the children through the vehicle or learning media at school. The application of learning about medicinal plants can be developed from children. From the educational learning of these medicinal plants, so that everyone can better know and utilize medicinal plants. Learning media associated with motor sensors can overcome the limitations possessed by children with special needs, especially children with hearing impairment and speech impaired that can improve the motor skills of the child. Motoric is the development of controlling body movement through coordinated activities between the nerves, muscles, brain [9].

Orthopedagogic can be called as a stand-alone science, because it has fulfilled the requirements of the discipline, namely the material object, the formal object, and the method itself. Object material Orthopedagogic has the purpose of education, education process, materials with delivery method, students, educational relationships with students, and so forth. Orthopedagogic Orthodontic Objects are extraordinary children, who have different disorders or problems to specialized educator services. Orthopedagogic method guarantees the arrival of the right to education to children extraordinary. Along with the current rapid technological developments, thus encouraging the educational process to be more interesting and applicable in order to improve the quality of education and learning interests of learners. Augmented Reality (AR) learning media is a technique of displaying objects directly by directing the camera to a real (marker) object. Based on existing problems, the research will be conducted is "Flashcard Computer Generated Imagery Medicinal Plants for Orthopedagogic Education" where the system is built later able to show interactive 3D learning media using a marker of flashcards about the medicinal plants of 20 medicinal plants. This is intended to facilitate the user especially in orthopedagogic education in recognizing the types of plants that are efficacious for treatment. In this research, the target is for 5th graders and 7 junior high school who are deaf, and tunawicara at SLB-B Dharma Wanita Sidoarjo. SBB-B Dharma Wanita Sidoarjo is one of the schools established to receive children with special needs.

\section{Related work}

\subsection{Medicinal plant}

Medicinal plants are a variety of plants that are recognized as plants for medicines. Medicinal plants can easily be found around us because Indonesia knows about herbal medicine since thousands of years ago [10]. So it can be concluded that medicinal plants are plants that are known, believed and proven to maintain health and even cure a disease. Traditional medicinal plants are plants that are proven to contain properties and processed traditionally by the community first and lowered down. There are 20 kinds of plants that are used as an object show in table 1 ,

Table 1. List of indonesian medicinal plant.

\begin{tabular}{|l|l|l|}
\hline No & $\begin{array}{l}\text { Bahasa Indonesia } \\
\text { Name }\end{array}$ & Latine Name \\
\hline 1 & Andong & Cordyline Fruticosa L \\
\hline 2 & Bawang Merah & Allium Cepa L \\
\hline 3 & Bawang Putih & Allium Sativum \\
\hline 4 & Belimbing Manis & Averhoa Carambola \\
\hline 5 & Daun Bawang & Allium Fistulosum \\
\hline 6 & Jahe & Zingiber sp \\
\hline 7 & Keladi Tikus & Typhonium Flagelliforme \\
\hline 8 & Kelapa & Cocos Nucifera \\
\hline 9 & Kentang & Solanum Tuberosum L \\
\hline 10 & Lidah Buaya & Aloe Vera \\
\hline 11 & Lidah Mertua & Sansevier \\
\hline 12 & Lobak & Raphanus Sativus L \\
\hline 13 & Mentimun & Cucumis Sativus \\
\hline 14 & Pandan & Pandanus \\
\hline 15 & Patah Tulang & Euphorbia Tirucali \\
\hline 16 & Serai & Cymbopogon Citratus \\
\hline 17 & Sirih Merah & Piper Crocatum \\
\hline 18 & Tumpang Air & Peperomia Pellucida \\
\hline 19 & Ubi Bit Merah & Beta Vulgaris L \\
\hline 20 & Wortel & Daucus Carota \\
\hline
\end{tabular}




\subsection{The orthopedagogic learning media is primarily on speech and hearing impairment}

The function of learning media in the learning process is as a medium of information delivery. Use of media in the learning process can arouse the desire and interest of children in learning. The learning media also helps the process of delivering the material and improving the child's understanding of the material. Education for children is Ortopedagogik extraordinary.

Etymologically Ortopedagogik comes from Greek, which consists of three words, the first word "ortho" derived from "orthos" which means straight, good, or healthy. The second word "peda" which comes from the word "paeda" which means "kid" and third "agogik" derived from the word "agogos" which means education. Thus, orthopedagogics can be interpreted as a science that discusses the education provided to help the child's extraordinary education [11]. Deaf people are when a person has limitations in language development (obtaining language). Speech impaired is when a person is experiencing abnormalities both in the pronunciation (articulation) of the language and his voice from normal talk resulting in difficulty in oral communication within the environment. Motoric is the development of controlling body movement through coordinated activities between the nerves, muscles, brain. Learning media associated with motor sensors can overcome the limitations possessed by children with special needs, especially children with hearing impairment and speech impaired that can improve the motor skills of the child.

Learning media for orthopedagogic education is a learning medium that can help children with special needs in learning. Children who are deaf and learning buddies most important is language learning because deaf and speech impaired difficulties in understanding vocabulary [12].

\subsection{Augmented reality}

Augmented Reality (AR) is a way to explore 3D objects and data, AR is a concept of fusion between Virtual Reality with World Reality. So the virtual objects of 2 Dimensions (2D) or 3 Dimensions (3D) seem to look real and unite with the real world. In AR technology, users can see the real world around them by adding virtual objects generated by the computer [13]. AR can be defined as taking its' three properties into consideration: combining the real world with virtual worlds, providing interaction, and presenting three dimensional (3D) objects.

Augmented Reality (AR) is one of the emerging technologies that might have potential and impact on learning and education. Besides that, the emergence and widespread ownership of mobile devices has lead to an increased interest to integrate the benefits of mobile learning and AR applications. The advancements of AR is now a growing rapidly on mobile device, reflected by the increase in handheld computing usage in recent years across the world and resulted in creating a subset of AR: mobile AR [14]. The augmented reality application using dynamic and static content complemented by audio and text is effective for teaching concepts of the fundamentals of electronics course. The perception of students is that learning the concepts is more easily when they use dynamic contents than when they use static ones [15]. Many studies have reported positive impact of Augmented Reality (AR) applications in primary, secondary and higher education in terms of student's motivation, learning gains, collaboration, interaction, learning attitudes and enjoyment, as reported in the literature review conducted by bacca [16],

The application was developed using a methodology for developing mobile AR applications for educational purposes from a collaborative creation process (CoCreation) and based on the Universal Design for Learning (UDL). A cross-sectional evaluation study was conducted to validate the Paint-cAR application in a real scenario. AR applied to different learning contexts in the framework of this work provides proper methods for developing professional competences from the contents used in this subject, but besides transversal competences are also developed such as: instrumental competences (analysis and synthesis skills, planning and organization skills, solving problems, managing information as well as taking decisions), personal competences (teamwork, work- place interpersonal relations skills, critical reasoning), systemic skills (autonomous learning, leadership, initiative, entrepreneur, motivation for quality) and others such as the skills to apply theoretical knowledge and put it into practice [17]. An interesting project based on the AR was created by European research project iTacitus - "Intelligent Tourism and Cultural Information through Ubiquitous Services. Heritage sites have huge amounts of information [18].

\section{Application design}

The app is designed is an Android-based augmented reality app, the goal for the application can be run easily using a smartphone. Stages of the design process:

- Create Marker

- Create 3D Model

- Create Loader Application

Create marker an image that has a certain pattern used to display the object. Images used as markers with .PNG and .JPG formats with sizes less than $2 \mathrm{MB}$ as shown in figure 1. A good marker is a marker that has lots of detail, good image contrast. The image will be used as a marker, first uploaded to the vuforia database, which will be converted by the vuforian marker engine. The converted file will generate a file with the format .unitypackage, to make a marker, in this application make 20 marker medicinal plants that have not been colored, and 20 markers of medicinal plants already. 20 markers of medicinal plants that have been colored were at http://developer.vuforia.com address and made into 1 database. Vuforia SDK is an AR-based Software Development Kit that uses mobile devices as a "magic lens" or glass to look into the AR world where real and virtual worlds co-exist. This app makes camera previews 
directly on the smartphone screen to represent the views of the physical world. Unity 3D or more commonly referred to as Unity is a programming software that is used to create various applications. The majority of Unity's use is for making Game applications. But with Unity, can create a variety of applications such as presentations, websites, can even be used to create Augmented Reality. 3D objects will be visible directly on the smartphone screen, so it will look 3D objects are in the real world. Vuforia SDK consists of 2 main components of QCAR library and target management system. Vuforiadpecialized for the manufacture of mobile applications, then the input is through a smartphone camera and the output is a smartphone screen. Create 3 Dimensional Modeling (3D) or also known as meshing is a process of making surface mathematical representation 3 Dimension of an object with certain software. Product modeling results are called 3D models.
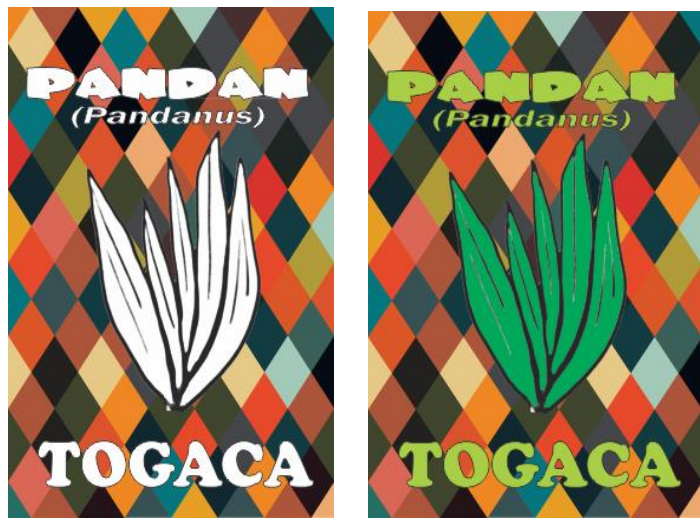

Fig. 1. Marker of medicinal plants before and after coloring.

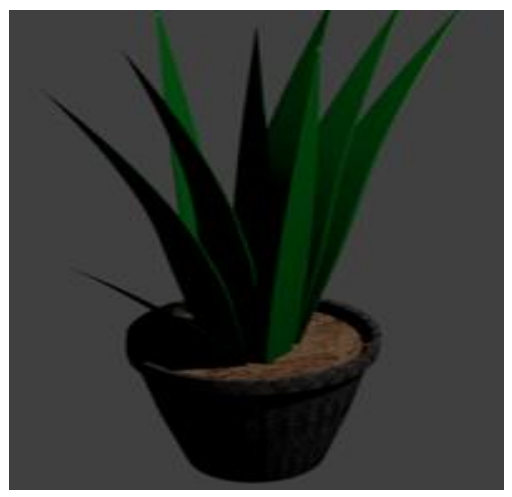

Fig. 2. One of the 3D Objects created using Blender software.

The 3D model can be displayed as a two-dimensional image through a process called 3D rendering. The final result of 3D images is a set of polygons. Models with more polygons require longer time to be rendered by the computer, as each surface has a texture and shading alone, this research 3D model will build by Blender. Blender is an Open Source System (OSS) or other term free software can be used in various Operating Systems (OS). Blender is a multifunction application that can be used for 3D Modeling, Animation, Video, Edit, Composition, and Game. 3D objects created there are 20 objects of medicinal plants. Figure 1 is one example of
3D objects in Blender software and figure 4 show 20 3D object of medicinal plants.

The loader application will show firstly printed versions of medicinal plant were designed. Then, according to the printed designs, story animation for card, 3D objects for flashcards were developed. Lastly, AR technology was integrated in these application by android mobile program. Android is a Linux-based operating system for mobile phones or smart phones and tablet computers. As an open application, android is an open platform for developers to create their own applications that can be used by various mobile devices.

\section{Result and discussion}

\subsection{Research result}

In this research produced an Augmented Reality application about medicinal plants that can display $3 \mathrm{D}$ objects of these medicinal plants by applying Augmented Reality technology. In this study used 20 medicinal plants.

\subsection{System implementation}

Augmented Reality application created is an android based application that can be accessed from android smartphone. Implementation of the application by detecting marker using smartphone with camera in application. The implementation results from the display show $3 \mathrm{D}$ objects as shown figure 3 below.

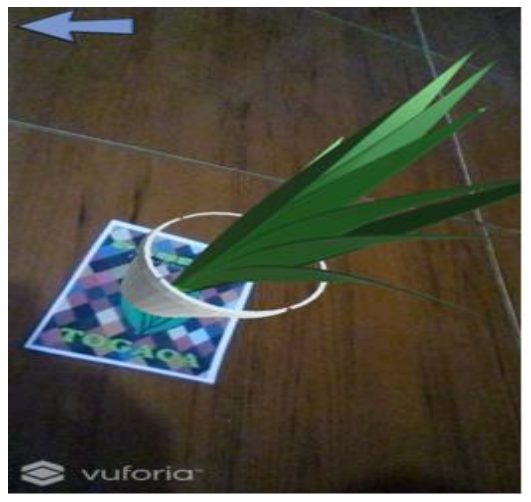

Figure 3. Display of marker detection and 3D objects of medicinal plants.
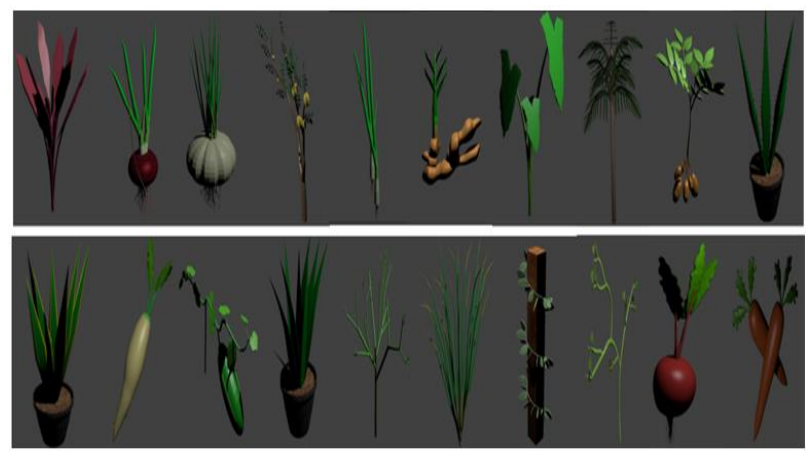

Fig. 4. 20 3D object of indonesian medicinal plants. 


\subsection{Application testing}

Testing conducted to determine the deficiencies in the application and to find out that the application made has met the criteria in accordance with the purpose of making the application. From the experimental results the comparison of the differentiated application load times is the AR Camera load process that can be affected from the number of installed applications, and the camera's quality on the smartphone, as shown in table 2 . Table 3 shown user responses to applications that have been created. Testing assessment method used is quantitative method based on sample data from user.

Table 2. Application load time comparison.

\begin{tabular}{|c|c|c|c|c|}
\hline Function & Phone 1 & Phone 2 & Phone 3 & Phone 4 \\
\hline $\begin{array}{l}\text { Load Splash } \\
\text { screen }\end{array}$ & $3 \mathrm{sec}$ & $3 \mathrm{sec}$ & $3 \mathrm{sec}$ & $3 \mathrm{sec}$ \\
\hline $\begin{array}{l}\text { Load AR } \\
\text { Camera }\end{array}$ & $22 \mathrm{sec}$ & $25 \mathrm{sec}$ & $10 \mathrm{sec}$ & $12 \mathrm{sec}$ \\
\hline $\begin{array}{l}\text { Load Object } \\
\text { 3D }\end{array}$ & $2 \mathrm{sec}$ & $2 \mathrm{sec}$ & $2 \mathrm{sec}$ & $2 \mathrm{sec}$ \\
\hline $\begin{array}{l}\text { Andorid } \\
\text { Version }\end{array}$ & $\begin{array}{c}\text { Marshmallow } \\
6.0\end{array}$ & $\begin{array}{c}\text { Lollipop } \\
5.1\end{array}$ & $\begin{array}{l}\text { Lollipop } \\
5.1\end{array}$ & $\begin{array}{l}\text { Lollipop } \\
5.1\end{array}$ \\
\hline Processor & $\begin{array}{c}\text { Quad Core } \\
1.0 \mathrm{GHz}\end{array}$ & $\begin{array}{c}\text { Quad } \\
\text { Core } \\
1.2 \mathrm{GHz}\end{array}$ & $\begin{array}{c}\text { Quad } \\
\text { Core } \\
1.3 \mathrm{GHz}\end{array}$ & $\begin{array}{c}\text { Quad Core } \\
1.3 \mathrm{GHz}\end{array}$ \\
\hline Camera & $8 \mathrm{MP}$ & $8 \mathrm{MP}$ & $8 \mathrm{MP}$ & $5 \mathrm{MP}$ \\
\hline $\begin{array}{l}\text { Merk / } \\
\text { Type }\end{array}$ & Coolpad E570 & $\begin{array}{l}\text { Oppo } \\
\text { A37 }\end{array}$ & $\begin{array}{c}\text { Huawei } \\
\text { Cun-L22 }\end{array}$ & $\begin{array}{l}\text { Samsung } \\
\text { Galaxy J2 }\end{array}$ \\
\hline Resolution & $720 \times 1280 p x$ & $\begin{array}{c}720 \mathrm{x} \\
1280 \mathrm{px}\end{array}$ & $\begin{array}{c}720 \mathrm{x} \\
1280 \mathrm{px}\end{array}$ & $\begin{array}{c}540 \times 960 \\
\mathrm{px}\end{array}$ \\
\hline Splash Load & Yes & Yes & Yes & Yes \\
\hline
\end{tabular}

Testing the application is a test conducted directly to the field by using a questionnaire about user responses to applications that have been made. Testing assessment method used is quantitative method based on sample data from 50 user respondence.

Table 3. User response.

\begin{tabular}{|c|c|c|c|}
\hline Quisioner & Agree & Less Agree & Disagree \\
\hline 1 & 50 & - & - \\
\hline 2 & 50 & - & - \\
\hline 3 & 50 & - & - \\
\hline 4 & 40 & 10 & - \\
\hline 5 & 35 & 15 & - \\
\hline 6 & 50 & - & - \\
\hline 7 & 50 & - & - \\
\hline
\end{tabular}

To know the user's response to this application, has been distributed questionnaire based on user target and done percentage using formula:

$$
\mathrm{Y}=\mathrm{A} / \mathrm{B} \times 100 \%
$$

Information: $\quad \mathrm{Y}=$ Precentage

$A=$ Number of respondents from each question

$\mathrm{B}=$ Number of respondents

The results of the questionnaire test to the respondents stated that the application can help the children in recognizing medicinal plants along with their Latin names, understanding the benefits of medicinal plants, and knowing the color and shape of medicinal plants.

\section{Conclusion}

\subsection{Conclusion}

From the results of developing Computer Flashcard Generated Imagery Medicinal Plant for Orthopedagogic Education can be drawn conclusion that is:

- In this application, 3D objects can be displayed properly. Camera quality and lighting can affect the 3D objects that will be displayed.

- Markers that do not get exposure directly can affect

- 3D objects.

- This app is designed to introduce medicinal plants to early childhood especially in Orthopedagogic education.

- This application uses Augmented Reality technology because it is more interactive when used by the user

- This application can help children especially in Orthopedagogic education to get to know the medicinal plants, the benefits of medicinal plants, the latin name of medicinal plants, and the shape, the color of medicinal plants.

\subsection{Suggestion}

This research is still basic research in the introduction of medicinal plants in the form of AR. Other researchers can develop, continue and make research as the basis for further research and application development such as:

- Addition of 3D objects of medicinal plants

- AR application on ornamental plants application of vegetables

\section{References}

1. A. W. Suparni, Herbal Nusantara, 1001 Ramuan Tradisional Asli Indonesia. (2012)

2. E. Zuhud, Potensi Hutan Tropika Indonesia 
Sebagai Penyangga Bahan Obat Alam untuk Kesehatan Bangsa, J. Bahan Alam Indones., no. June, p. 8, (2009)

3. M. Rahayu, S. Sunarti, D. Sulistiarini, and S. Prawiroatmodjo, Pemanfaatan Tumbuhan Obat secara Tradisional oleh Masyarakat Lokal di Pulau Wawonii, Sulawesi Tenggara Traditonal use of medicinal herbs by local community of Wawonii island, Southeast Sulawesi, Biodiversitas, vol. 7, pp. 245-250, (2006)

4. L. Nurrani, Pemanfaatan Tradisional Tumbuhan Alam Berkhasiat Obat Oleh Masyarakat di Sekitar Cagar Alam Tengale, Info BPK Manad., vol. 3, pp. 1-22, (2013)

5. D. Harniawati and T. Y. Widya, Edukatif Tentang Penerapan Hidup Sehat Pada Sekolah Dasar Di Kediri Tocap (Toga Education Programs) Through Improving Educative Teaching For Implementing Of Healthy Life At Elementary School In Kediri 1084," Pros. Semin. Nas. Biol., vol. XI, pp. 1084 1087, (2014)

6. Menteri Pendidikan Nasional and r. Indonesia, Pendidikan Inklusif bagi Peserta Didik yang Memiliki Kelainan dan Memiliki Potensi Kecerdasan dan/atau Bakat Istimewa, Peratur. MENTERI Pendidik. Nas. REPUBLIK Indones., vol. 70, (2009)

7. R. M. Yilmaz, Educational magic toys developed with augmented reality technology for early childhood education, Comput. Human Behav. vol. 54, pp. 240-248, (2016)

8. R. Dijaya Augmented Reality Untuk Kelompok Bermain" Semin. Nas. Inov. Teknol. UNP KEDIRI, pp. 1-6, (2017)

9. M. Irvan, Pengetahuan mahasiswa pg-paud unipa surabaya tentang pendidikan inklusif, J. Buana Pendidik., vol. XIII, no. 24, pp. 155-164, (2017)

10. Kelompok Masyarakat Desa Sirnasari, Tumbuhan Obat Halimun. (2008)

11. Casmini, Ortopedagogik Umum, Diktat Kuliah, Jurusan Pendidikan Luar Biasa, (2010)

12. Dirjen Direktorat Pendidikan Luar Biasa, Pedoman Umum Penyelenggaraan Pendidikan Inklusif, no. 70. (2007)

13. J. Carmigniani and B. Furht, Handbook of Augmented Reality. (2011)

14. D. Nincarean, M. B. Alia, N. D. A. Halim, and M. H. A. Rahman, Mobile Augmented Reality: The Potential for Education, Procedia - Soc. Behav. Sci., vol. 103, pp. 657-664, (2013)

15. C. Diaz, M. Hincapié, and G. Moreno, How the Type of Content in Educative Augmented Reality Application Affects the Learning Experience, Procedia Comput. Sci., vol. 75, no. Vare, pp. 205212, (2015)

16. J. Bacca, S. Baldiris, R. Fabregat, Kinshuk, and S. Graf, Mobile Augmented Reality in Vocational Education and Training, Procedia Comput. Sci., vol. 75, no. Vare, pp. 49-58, (2015)

17. J. Martín-Gutiérrez, P. Fabiani, W. Benesova, M. D. Meneses, and C. E. Mora, Augmented reality to promote collaborative and autonomous learning in higher education, Comput. Human Behav., vol. 51, pp. 752-761, (2015)

18. J. Kysela and P. Štorková, Using Augmented Reality as a Medium for Teaching History and Tourism, Procedia - Soc. Behav. Sci., vol. 174, pp. 926-931, (2015) 